\title{
IMPLEMENTASI AKUNTANSI ZAKAT DAN INFAK/SEDEKAH PADA BAZNAS KABUPATEN TEGAL
}

\author{
Muhammad Arif Budiman 1); Amrie Firmansyah ${ }^{2)^{*}}$ \\ 1) budiman4441@gmail.com, Politeknik Keuangan Negara STAN \\ 2) amrie@pknstan.ac.id, Politeknik Keuangan Negara STAN \\ *email korespondensi
}

\begin{abstract}
This study aims to review the implementation of zakat and infaq accounting at the BAZNAS Tegal Regency. The method used in this research is qualitative by interviewing the informant. The informant is the head of the financial division of the BAZNAS Tegal Regency. Questions posed to informants include the process of preparing financial statements. Besides, a literature review was used to confirm the data obtained from the interview results. This study concludes that most of the recognition, measurement, presentation and disclosure of zakat and infaq by BAZNAS Tegal Regency is under financial accounting standards. Based on this research, BAZNAS Tegal Regency needs to place employees with a background in accounting education.
\end{abstract}

Keywords: sharia accounting standard, organization, infaq, zakat

\begin{abstract}
Abstrak
Penelitian ini bertujuan untuk mengkaji implementasi akuntansi zakat dan infaq pada BAZNAS Kabupaten Tegal. Metode yang digunakan dalam penelitian ini adalah kualitatif dengan mewawancarai informan. Informan adalah kepala bagian keuangan BAZNAS Kabupaten Tegal. Pertanyaan yang diajukan kepada informan meliputi proses penyusunan laporan keuangan. Selain itu, studi pustaka digunakan untuk mengkonfirmasi data yang diperoleh dari hasil wawancara. Penelitian ini menyimpulkan bahwa sebagian besar pengakuan, pengukuran, penyajian dan pengungkapan zakat dan infaq oleh BAZNAS Kabupaten Tegal berada di bawah standar akuntansi keuangan. Berdasarkan penelitian ini, BAZNAS Kabupaten Tegal perlu menempatkan pegawai yang berlatar belakang pendidikan akuntansi.
\end{abstract}

Kata Kunci : akuntansi syariah, organisasi, infaq, zakat

\section{PENDAHULUAN}

Dari sudut pandang akuntansi, permasalahan umum yang terjadi dalam hal pengelolaan dana zakat adalah banyak Organisasi Pengelola Zakat (OPZ) yang menyajikan laporan keuangannya hanya berdasarkan penerimaan dan pengeluaran kas yang terjadi sehingga memunculkan saldo di neraca (Fathonah, 2013). Beberapa OPZ juga tidak mengelompokkan antara saldo dana zakat, dana infak, dana amil di dalam sebuah neraca (Arief et al., 2017; Pratama \& Roziq, 2017). Saldo dana yang bercampur tersebut tentunya akan menyulitkan manajemen untuk melakukan pengelolaan karena tidak dapat mengelompokkan berapa porsi amil dan berapa porsi untuk diserahkan ke mustahik. Permasalahan tersebut menunjukkan bahwa sumber daya manusia yang dimiliki sebagian OPZ masih minim pengetahuan tentang akuntansi zakat. Sularno (2010) menyimpulkan bahwa OPZ milik Pemerintah Daerah Istimewa Yogyakarta memiliki kendala berupa pegawai pengelola zakat yang merangkap jabatan, sehingga pekerjaan di OPZ hanya digunakan sebagai pekerjaan sampingan.

Pengelolaan zakat yang baik oleh OPZ akan berpengaruh pada kepercayaan masyarakat untuk sadar dan bersedia mengeluarkan zakatnya (Ramadhita, 2012). Stigma masyarakat terhadap OPZ yang rentan terjadi penyelewengan akan menurun seiring tumbuhnya pengelolaan zakat yang profesional, transparan, terbuka, dan akuntabel (Istikhomah \& Asrori, 2013). Dengan meningkatnya kepercayaan masyarakat tentu saja akan memaksimalkan penerimaan zakat (Ramadhita, 2012) sehingga pendayagunaan dan pendistribusiannya kepada masyarakat dapat mencapai tujuan yang diiginkan yaitu mengurangi tingkat kemiskinan di masyarakat.

Peraturan akuntansi zakat sebagaimana dinyatakan dalam pada PSAK 109 (Ikatan Akuntan Indonesia, 2010), kurang mendapat perhatian dari sebagian OPZ, sedangkan penelitian 
yang mengulas terkait dengan akuntansi zakat masih relatif sedikit. Penelitian sebelumnya terkait tentang akuntansi zakat telah dilakukan oleh Istutik (2013) yang mengulas implementasi akuntansi zakat pada lembaga amil zakat di Kota Malang yang menyimpulkan bahwa lembaga amil tersebut belum menerapkan standar akuntansi keuangan sebagaimana PSAK 109. Penyusunan laporan keuangan yang dilakukan oleh lembaga amil zakat tersebut hanya dalam bentuk laporan penerimaan dan pengeluaran kas. Fitria (2013) menyimpulkan bahwa amil belum menyajikan laporan posisi keuangan dan laporan perubahan dana pada laporan keuangan BAZNAS Kota Pekanbaru. Sementara itu, Nikmatuniayah \& Marliyati (2015) menyimpulkan bahwa laporan perubahan aset kelolaan belum lengkap tersedia pada lembaga amil zakat di Kota Semarang. Aziz (2014) menyimpulkan bahwa amil tidak menyusun laporan arus kas pada Rumah Zakat Semarang. Ritonga (2017) menunjukkan bahwa penerapan akuntansi zakat pada BAZNAZ Sumatera Utara belum sepenuhnya sesuai dengan PSAK 109. Penelitian lainnya juga menyimpulkan bahwa lembaga amil zakat dan BAZNAZ masih belum menerapkan pelaporan keuangan sebagaimana PSAK 109 (Andriana \& Sayidah, 2018; Angraeni et al., 2016; Habibatulloh, 2021; Hasibuan, 2020; Isman, 2018; Latifah \& Mahrus, 2021; Loen, 2018; Nurabiah et al., 2019; Pertiwi et al., 2017).

Berbeda dengan penelitian sebelumnya yang mengulas tentang akuntansi zakat pada amil yang telah lama berdiri, penelitian ini bertujuan untuk mengulas implementasi penerapan PSAK 109 (Ikatan Akuntan Indonesia, 2010) terkait dengan akuntansi zakat, dan infak/sedekah secara lebih komprehensif pada amil yang baru berdiri yaitu BAZNAS Kabupaten Tegal. BAZNAS Kabupaten Tegal merupakan OPZ yang didirikan tahun 2019, sehingga tahun tersebut merupakan tahun pertama OPZ menyusun laporan keuangan. Aktivitas yang dilakukan BAZNAS Kabupaten Tegal tidak terbatas bukan hanya mengelola penerimaan dan penyaluran dana zakat dari masyarakat semata, tetapi juga terlibat dalam kegiatan sosial dan transaksi yang tidak biasa seperti memberikan bantuan berupa renovasi rumah tidak layak huni (Setda Kabupaten Tegal, 2020) dan bekerja sama dengan karang taruna melakukan penyaluran hewan kurban (Baznas, 2019). Kegiatan dan transaksi tersebut sangat penting untuk diulas dari sudut pandang akuntansi. Penelitian ini diharapkan dapat menjadi pertimbangan bagi IAI dalam melakukan pengembangan PSAK 109 dan bagi pemerintah dalam rangka menghasilkan regulasi terkait zakat dan infak/sedekah, serta bagi masyarakat untuk mendorong semangat berzakat.

\section{KAJIAN PUSTAKA}

Dari sudut pandang syariah, akuntansi dalam suatu organisasi dapat diterapkan denan prinsip syariah (Harahap, 2018). Menurut Djuanda (2006), organisasi pengelola zakat adalah lembaga yang mengelola dana zakat dan infak/sedekah. Badan amil zakat merupakan organisasi pengelola zakat yang dibentuk pemerintah dalam mengumpulkan, mendistribusikan, dan memberdayakan zakat sesuai ketentuan agama (Soemitra, 2009). Organisasi pengelola zakat termasuk ke dalam golongan entitas non profit dan bersifat syariah, di mana laporan keuangannya pasti berbeda dengan organisasi konvensional yang berorientasi pada profit.

PSAK 109 tentang Akuntansi Zakat dan Infak/Sedekah yang disahkan oleh Dewan Standar Akuntansi Syariah (DSAK) Ikatan Akuntan Indonesia (IAI) pada tanggal 06 April 2010 yang berlaku setelah tanggal 01 Januari 2012 dan bersifat prospektif (Ikatan Akuntan Indonesia, 2010). PSAK 109 mengatur proses - proses operasional dan dasar akuntansi yang berhubungan dengan penentuan, penilaian, pendapatan, dan penetapan kadar zakat dan distribusi manfaat ke dalam pos-pos sesuai dengan syariat serta hukum islam (Ikatan Akuntan Indonesia, 2010). Standar keuangan ini hadir dengan tujuan untuk mengatur pengakuan, pengukuran, penyajian, dan pengungkapan transaksi zakat dan infak/sedekah. Ruang lingkup penerapan PSAK ini adalah untuk entitas syariah yang memiliki kegiatan utama untuk menerima dan menyalurkan 
zakat dan infak/sedekah. Laporan keuangan entitas syariah yang melakukan kegiatan menerima dan menyalurkan zakat tetapi bukan merupakan kegiatan utamanya mengacu pada PSAK 101 tentang Penyajian Laporan Keuangan Syariah (Ikatan Akuntan Indonesia, 2016).

Entitas syariah yang menerima dan menyalurkan zakat dan infak/sedekah, yang selanjutnya disebut amil, dibentuk dengan tujuan untuk mengumpulkan dan menyalurkan zakat dan infak/sedekah. PSAK 109 wajib diterapkan oleh amil setelah mendapatkan izin dari pemerintah pusat, sehingga mampu menyusun laporan keuangan dengan baik (Ikatan Akuntan Indonesia, 2010). Laporan keuangan amil zakat bertujuan sebagai alat pertanggungjawaban dan bukti transparansi pengelolaan keuangan kepada para pemangku kepentingan dan dapat digunakan sebagai dasar evaluasi kinerja organisasi (Amelia \& Qibtiyah, 2015) .

\section{METODE}

Penelitian ini dilakukan selama periode Maret sampai dengan Juni 2020 dengan menggunakan metode kualitatif. Data penelitian diperoleh melalui wawancara dengan informan yaitu kepala divisi keuangan BAZNAS Kabupaten Tegal. Informan dalam penelitian bertanggungjawab dalam melakukan pencatatan transaksi dan menyusun laporan keuangan, dan memiliki pemahaman yang memadai atas akuntansi zakat yang dilaksanakan BAZNAS Kabupaten Tegal. Pertanyaan yang diajukan dalam wawancara meliputi gambaran umum amil, perlakuan amil terhadap transaksi zakat sampai dengan laporan keuangan yang telah disusun. Selain itu, penelitian ini juga menggunakan analisis konten yang bersumber dari laporan keuangan BAZNAS Kabupaten Tegal tahun 2019 sebagai informasi tambahan analisis yang dilakukan dalam penelitian ini. Hasil dari wawancara dilakukan melalui coding untuk mendapatkan data yang digunakan dalam dalam analisis (Saputra \& Firmansyah, 2018). Analisis dilakukan dengan menggunakan data coding wawancara dan data laporan keuangan, dan mengkonfirmasikan dalam PSAK 109.

\section{HASIL DAN PEMBAHASAN}

\section{Pengakuan zakat dan infak/sedekah di BAZNAS Kabupaten Tegal}

Penerimaan dana zakat di BAZNAS Kabupaten Tegal terdiri dari penerimaan kas, penerimaan bank, dan dana nonkas. Penerimaan kas merupakan penerimaan dari muzaki yang diterima langsung oleh kasir dan berwujud uang tunai. Sementara itu, penerimaan bank merupakan penerimaan melalui rekening bank yang dimiliki BAZNAS Kabupaten Tegal. Penerimaan dana nonkas adalah penerimaan sumbangan berwujud aset nonkas. BAZNAS Kabupaten Tegal sudah memisahkan pos - pos penerimaan dana antara zakat dan infak/sedekah. Terhadap dana zakat yang terkumpul, BAZNAS Kabupaten Tegal mengakui 12,5\% nya sebagai dana amil. Pengakuan dana amil tersebut akan mengurangi saldo dana zakat. Pencatatan sebagian dana zakat untuk bagian amil dilakukan setiap melakukan pencatatan penerimaan zakat.

Secara umum jurnal pengakuan penerimaan zakat yang dilakukan oleh BAZNAS Kabupaten Tegal sudah sesuai PSAK 109 yaitu sebagai penambah dana zakat, walaupun masih terdapat adanya kesalahan pencatatan periode transaksi. Pencatatan dana zakat yang diterima lewat bank dicatat setiap awal bulan (Ikatan Akuntan Indonesia, 2010). Dana zakat seharusnya diakui pada saat diterima amil yaitu saat masuk ke rekening amil (Ikatan Akuntan Indonesia, 2010).

Penyaluran dana zakat di BAZNAS Kabupaten Tegal diakui sebagai pengurang dana zakat. Penentuan jumlah atau persentase bagian dana zakat untuk masing - masing mustahik berpedoman pada Rencana Kerja dan Anggaran Tahunan (RKAT). RKAT merupakan naskah yang memuat program kerja dan anggaran kegiatan BAZNAS untuk satu tahun periode 
pelaporan. Biaya yang timbul atas kegiatan penyaluran dana zakat dan kegiatan operasional lainnya diambil dari dana amil.

Dalam menyalurkan dana zakat, BAZNAS Kabupaten Tegal bekerja sama dengan beberapa amil masjid di wilayah Kabupaten Tegal. Penyaluran zakat melalui amil lain diakui sebagai piutang penyaluran. Piutang tersebut akan dieliminasi dan diakui sebagai penyaluran zakat ketika telah menerima Laporan Pertanggung Jawaban (LPJ) pendistribusian zakat. BAZNAS Kabupaten Tegal menyerahkan ujrah sebesar 5\% dari dana yang disalurkan kepada amil lain. Dana ujrah tersebut berasal dari saldo dana amil. Tidak terdapat transaksi pinjaman dana bergulir atau qardhul hasan (dana kebajikan). Penyaluran dana zakat atas aset kelolaan juga tidak ada.

Penerimaan dana infak/sedekah di BAZNAS Kabupaten Tegal dikelompokan menjadi penerimaan infak/sedekah terikat (IST) dan infak/sedekah tidak terikat (ISTT). Selama tahun 2019, tidak terdapat transaksi penerimaan infak/sedekah yang bersifat terikat. BAZNAS Kabupaten Tegal mengakui penerimaan infak/sedekah sebagai penambah saldo dana infak/sedekah.

Terhadap dana infak/sedekah yang terkumpul, BAZNAS Kabupaten Tegal mengakui $20 \%$ nya sebagai dana amil. Pengakuan dana amil tersebut akan mengurangi saldo dana infak/sedekah. Dana amil digunakan untuk kegiatan pengumpulan dan penyaluran zakat dan infak/sedekah (Rahman, 2015). Belanja operasional juga sepenuhnya menggunakan dana amil. Tidak ada tambahan dana yang bersumber dari APBD Kabupaten Tegal tahun 2019. Pencatatan sebagian dana infak/sedekah untuk bagian amil dilakukan setiap melakukan pencatatan penerimaan zakat.

Secara umum pengakuan penerimaan infak/sedekah sudah sesuai PSAK 109 (IAI, 2010) yaitu sebagai penambah dana infak/sedekah, namun terdapat kesalahan pencatatan periode transaksi. Pencatatan dana infak/sedekah yang diterima melalui bank akan diakui sekaligus pada awal bulan. Menurut PSAK 109 (IAI, 2010), dana infak/sedekah seharusnya diakui pada saat diterima oleh amil yaitu saat masuk ke rekening amil.

Penyaluran infak/sedekah di BAZNAS Kabupaten Tegal diakui sebagai pengurang dana infak/sedekah. Pada tahun 2019 seluruh penyaluran infak/sedekah merupakan infak/sedekah tidak terikat. Penentuan jumlah atau persentase bagian dana infak/sedekah untuk masyarakat yang membutuhkan berpedoman pada Rencana Kerja dan Anggaran Tahunan (RKAT). Biaya yang timbul atas kegiatan penyaluran dana infak/sedekah dan kegiatan operasional lainnya diambil dari dana amil. Porsi dana amil yang diambil dari penerimaan infak/sedekah berubah mengikuti kondisi keuangan amil dengan kebijakan kepala kantor, namun tetap dibawah batas maksimal $20 \%$.

Dalam menyalurkan dana infak/sedekah, BAZNAS Kabupaten Tegal bekerja sama dengan beberapa amil masjid di wilayah Kabupaten Tegal. Penyaluran infak/sedekah melalui amil lain diakui sebagai piutang penyaluran. Piutang tersebut akan dieliminasi dan diakui sebagai penyaluran infak/sedekah ketika telah menerima Laporan Pertanggung Jawaban (LPJ) pendistribusian infak/sedekah. BAZNAS Kabupaten Tegal menyerahkan ujrah sebesar 5\% dari dana yang disalurkan kepada amil lain. Dana ujrah tersebut berasal dari saldo dana amil. Tidak terdapat transaksi pinjaman dana bergulir atau qardhul hasan (dana kebajikan). Penyaluran dana infak/sedekah atas aset kelolaan juga tidak ada.

Tabel 1. Analisis pengakuan zakat dan infak/sedekah

\begin{tabular}{llll}
\hline No. & \multicolumn{1}{c}{ Isi PSAK } & Implementasi pada BAZNAS Kab. Tegal & Keterangan \\
\hline 1 & $\begin{array}{l}\text { Penerimaan zakat diakui pada saat kas } \\
\text { atau aset nonkas diterima. }\end{array}$ & $\begin{array}{l}\text { Zakat yang diterima melalui bank dicatat } \\
\text { saat dilakukan rekap pencatatan oleh amil. }\end{array}$ & Tidak Sesuai
\end{tabular}


2 Amil berhak mengambil bagian dari zakat untuk menutup biaya operasional dalam melaksanakan fungsinya.

3 Beban penghimpunan dan penyaluran zakat harus diambil dari porsi amil

$4 \quad$ Zakat yang disalurkan melalui amil lain tetapi belum diterima oleh mustahik nonamil, belum memenuhi pengertian zakat telah disalurkan

5 Bagian dana infak/sedekah yang disalurkan untuk amil diakui sebagai penambah dana amil.

6 Jumlah bagian untuk penerima infak/sedekah ditentukan oleh amil sesuai dengan kebijakan amil.

7 Penyaluran infak/sedekah kepada amil lain mengurangi saldo dana infak/sedekah apabila amil tidak akan menerima kembali aset infak/sedekah yang disalurkan tersebut.
Amil mengambil bagian sebesar $12,5 \%$ atas dana zakat yang diterima.

Sesuai

Beban - beban yang timbul atas

penghimpunan dan penyaluran zakat diambil

Sesuai dari porsi amil

Zakat yang disalurkan melalui amil lain baru diakui sebagai penyaluran setelah menerima LPJ.

Sesuai

Mengakui dana amil sebesar maksimal 20\% dari infak/sedekah yang diterima, nilai ini berubah sesuai kebijakan kepala kantor. Penentuan porsi penerima infak/sedekah mengacu pada RKAT yang telah disusun.

Sesuai

Sesuai

Penyaluran infak/sedekah kepada amil lain diakui sebagai piutang terlebih dahulu, menjadi penyaluran infak/sedekah apabila telah memperoleh LPJ dari amil lain tersebut.

\section{Pengukuran zakat dan infak/sedekah di BAZNAS Kabupaten Tegal}

Berdasarkan wujudnya, penerimaan zakat digolongkan menjadi penerimaan kas dan penerimaan aset nonkas (Ikatan Akuntan Indonesia, 2010). Untuk penerimaan zakat berwujud kas diukur sebesar jumlah yang diterima. Terhadap penerimaan zakat berwujud aset nonkas akan diukur nilainya oleh tim penilai BAZNAS Kabupaten Tegal ke dalam satuan rupiah. BAZNAS Kabupaten Tegal telah memisahkan pos - pos tersendiri untuk penerimaan dana antara zakat dan infak/sedekah.

BAZNAS Kabupaten Tegal tidak melakukan transaksi penerimaan dana zakat dari amil lain selama periode pencatatan 2019. Aset nonkas yang diterima sesegera mungkin langsung diserahkan kepada muzaki. Selama tahun pelaporan 2019, belum pernah terjadi pengukuran atas penurunan nilai aset zakat nonkas yang dilakukan BAZNAS Kabupaten Tegal.

Dana zakat berkurang sesuai dengan jumlah yang diserahkan apabila dilakukan dalam bentuk kas (Ikatan Akuntan Indonesia, 2010). Atas penyaluran berupa aset nonkas, dicatat sebesar nilai tercatat dari aset nonkas tersebut. Penentuan jumlah atau persentase bagian dana zakat untuk masing - masing mustahik berpedoman pada Rencana Kerja dan Anggaran Tahunan (RKAT). RKAT merupakan naskah yang memuat program kerja dan anggaran kegiatan BAZNAS untuk satu tahun periode pelaporan.

Baznas Kabupaten Tegal telah melakukan pengukuran dana zakat dan infak/sedekah secara terpisah. Infak/sedekah yang diterima diukur sesuai jumlah yang kas yang diterima. Terhadap penerimaan infak/sedekah berwujud aset nonkas akan diukur sesuai nilai wajarnya. Penentuan nilai wajar tersebut dilakukan oleh tim penilai BAZNAS Kabupaten Tegal.

Terhadap penyaluran dana infak/sedekah kepada masyarakat, amil mengurangi saldo dana infak/sedekah sesuai dengan jumlah kas yang diserahkan. Atas penyaluran berupa aset nonkas, dicatat sebesar nilai tercatat dari aset nonkas tersebut. Selama tahun 2019 Aset nonkas yang diterima sesegera mungkin langsung diserahkan kepada masyarakat yang membutuhkan, sehingga belum pernah terjadi penurunan nilai aset zakat nonkas. 
Tabel 2. Analisis pengukuran zakat dan infak/sedekah

\begin{tabular}{|c|c|c|c|}
\hline No. & Isi PSAK & Implementasi pada BAZNAS Kab. Tegal & Keterangan \\
\hline 1. & $\begin{array}{l}\text { Zakat yang diterima menambah saldo } \\
\text { dana zakat sebesar jumlah yang } \\
\text { diterima dalam bentuk kas, dan } \\
\text { sebesar nilai wajar untuk nonkas. }\end{array}$ & $\begin{array}{l}\text { Amil mencatat sebesar nilai kas dan } \\
\text { dilakukan penilaian oleh tim penilai } \\
\text { terhadap penerimaan nonkas. }\end{array}$ & Sesuai \\
\hline 2. & $\begin{array}{l}\text { Zakat yang disalurkan mengurangi } \\
\text { dana zakat sebesar: a) jumlah yang } \\
\text { diserahkan, apabila dalam bentuk } \\
\text { kas; b) nilai tercatat terhadap aset } \\
\text { nonkas. }\end{array}$ & $\begin{array}{l}\text { Amil mencatat penyaluran sebesar nilai kas } \\
\text { dan nilai tercatat untuk nonkas. }\end{array}$ & Sesuai \\
\hline 3. & $\begin{array}{l}\text { Infak/sedekah yang diterima } \\
\text { menambah saldo dana infak/sedekah } \\
\text { sebesar jumlah yang diterima dalam } \\
\text { bentuk kas, dan sebesar nilai wajar } \\
\text { untuk nonkas. }\end{array}$ & $\begin{array}{l}\text { Amil mencatat sebesar nilai kas dan } \\
\text { dilakukan penilaian oleh tim penilai } \\
\text { terhadap aset nonkas. }\end{array}$ & Sesuai \\
\hline 4. & $\begin{array}{l}\text { Penentuan nilai wajar aset nonkas } \\
\text { yang diterima menggunakan harga } \\
\text { pasar, apabila tidak tersedia maka } \\
\text { dapat menggunakan metode } \\
\text { penentuan nilai wajar lainnya sesuai } \\
\text { dengan SAK yang relevan }\end{array}$ & $\begin{array}{l}\text { Penilaian aset nonkas dinilai oleh tim penilai } \\
\text { yang dimiliki amil. }\end{array}$ & Sesuai \\
\hline 5. & $\begin{array}{l}\text { Penyaluran infak/sedekah diakui } \\
\text { sebagai pengurang dana } \\
\text { infak/sedekah sebesar: a) jumlah } \\
\text { yang diserahkan, dalam hal berbentuk } \\
\text { kas; b) nilai tercatat apabila dalam } \\
\text { bentuk nonkas. }\end{array}$ & $\begin{array}{l}\text { Amil mencatat penyaluran sebesar nilai kas } \\
\text { dan nilai tercatat untuk nonkas. }\end{array}$ & Sesuai \\
\hline
\end{tabular}

\section{Penyajian zakat dan infak/sedekah di BAZNAS Kabupaten Tegal}

Komponen penyajian laporan keuangan 2019 BAZNAS Kabupaten Tegal terdiri dari laporan posisi keuangan, laporan perubahan dana, dan laporan perubahan aset kelolaan. Penyusunan ketiga laporan tersebut dilakukan dengan menggunakan Aplikasi Excel yang didalam nya telah di program sesuai dengan kebutuhan. Aplikasi Simba yang merupakan aplikasi dari BAZNAS pusat baru digunakan sebatas pelaporan dana masuk dan data muzaki. BAZNAS Kabupaten Tegal menyajikan dana zakat, dana infak/sedekah, dan dana amil secara terpisah dalam laporan posisi keuangan. Seluruh akun dalam laporan perubahan aset kelolaan bernilai nol, munculnya nilai nol pada laporan perubahan aset kelolaan terjadi karena amil belum memiliki aset kelolaan. Sampai dengan dilakukannya wawancara dengan narasumber (27 Juni 2020), amil belum menyusun laporan arus kas dan catatan atas laporan keuangan 2019. Laporan Posisi Keuangan 2019 BAZNAS Kabupaten Tegal terdiri dari tiga bagian yaitu aset, liabilitas, dan saldo dana. Bagian aset terdiri dari aset lancar, aset tetap, dan aset kelolaan. Aset lancar terdiri atas tujuh akun yaitu kas dan setara kas, persediaan, barang berharga, piutang, beban dibayar dimuka, uang muka, dan investasi.

Pada bagian aset lancar akun yang memiliki nilai saldo hanya kas dan setara kas, dan akun piutang. Kas dan setara kas memiliki saldo sebesar Rp 837.862.112, sejumlah kas ini berasal dari saldo dana zakat, dana infak/sedekah, dana amil, dan dana non syariah yang tersisa di akhir tahun. Akun Piutang memiliki saldo Rp 612.118.692, nilai ini berasal dari penyaluran dana zakat dan infak/sedekah (termasuk ujrah) yang disalurkan melalui amil lain yang belum diterima LPJ nya. Persediaan tidak memiliki saldo karena setiap pembelian persediaan langsung diakui sebagai belanja, dan pada akhir periode tidak melakukan inventaris sisa persediaan. Akun barang berharga, biaya dibayar dimuka, uang muka, dan investasi memiliki saldo nol. Aset tetap dan aset kelolaan disajikan secara bersih tanpa akun akumulasi penyusutan. BAZNAS Kabupaten Tegal berlokasi di gedung yang dipinjamkan oleh pemerintah Kabupaten 
Tegal sehingga tidak memiliki akun gedung dan bangunan di laporan posisi keuangannya. BAZNAS Kabupaten Tegal juga belum memiliki kendaraan dan perlengkapan apa pun sehingga saldo aset tetap bernilai nol. Akun aset kelolaan pada tahun pelaporan 2019 memiliki saldo nol.

Bagian liabilitas pada laporan posisi keuangan BAZNAS Kabupaten Tegal terdiri dari utang penyaluran, biaya yang masih harus dibayar, hutang pihak ketiga, hutang lain-lain, dan hutang murabahah. Seluruh akun tersebut bernilai saldo nol. BAZNAS Kabupaten Tegal memiliki tagihan pembayaran gaji pegawai, listrik, dan air, namun tidak mengakuinya sebagai liabilitas. Bagian saldo dana terdiri dari saldo dana zakat, saldo dana infak/sedekah, saldo dana amil, saldo dana hibah, saldo dana APBD, dan saldo dana non syariah. Saldo dana zakat bernilai Rp 1.044.729.547, nilai tersebut merupakan sisa penerimaan zakat 2019 yang belum digunakan dan ditambah dengan saldo awal tahun. Saldo dana infak/sedekah bernilai Rp 242.577.690. Saldo dana amil bernilai Rp 158.841.308. Saldo dana hibah dan saldo dana APBD bernilai nol. Saldo dana non syariah bernilai Rp 3.832.259, nilai tersebut berasal dari penerimaan bagi hasil atas dana yang tersedia (idle cash) di rekening bank syariah setelah dikurangi biaya administrasi oleh bank.

BAZNAS Kabupaten Tegal menyajikan laporan perubahan dana yang terdiri dari lima bagian, yaitu dana zakat, dana infak/sedekah, dana amil, dana hibah, dana APBD, dan dana non syariah. Penyajian dana infak/sedekah telah dipisahkan antara yang bersifat terikat dengan yang bersifat tidak terikat sebagaimana temuan Hisamuddin \& Solikha (2014). Nilai akhir dari masing masing bagian tadi akan menjadi saldo akhir yang disajikan pada bagian saldo dana di laporan posisi keuangan. Pada bagian dana zakat, BAZNAS Kabupaten Tegal menyajikan penerimaan yang terdiri atas penerimaan dana zakat maal, zakat fitrah, hasil penempatan zakat, selisih lebih nilai tukar zakat, dan penerimaan lain lain dana zakat. Akun penerimaan hasil penempatan zakat memiliki saldo Rp 1.015 .985 berasal dari bagi hasil atas dana yang tersedia (idle cash) di rekening zakat bank syariah setelah dikurangi biaya administrasi oleh bank. BAZNAS Kabupaten Tegal telah menyajikan penyaluran zakat kepada masing - masing golongan yaitu amil, fakir, miskin, mualaf, riqab, gharimin, fisabilillah, dan ibnu sabil.

Pada bagian dana infak/sedekah, BAZNAS Kabupaten Tegal telah menyajikan penerimaan infak/sedekah yang bersifat terikat dan tidak terikat secara terpisah. Dalam subbagian penerimaan terdapat akun bagi hasil penempatan infak sebesar Rp 4.182.136. Nilai tersebut berasal dari bagi hasil atas dana yang tersedia (idle cash) di rekening infak/sedekah bank syariah setelah dikurangi biaya administrasi oleh bank.

Dana APBD dalam laporan perubahan dana masih bersaldo nol, hal tersebut terjadi karena BAZNAS Kabupaten Tegal tidak mendapat dana dari pemerintah daerah selama tahun 2019. Untuk tahun 2020 BAZNAS Kabupaten Tegal diproyeksikan akan mendapat porsi APBD sebesar Rp 100.000.000. Dana APBD tersebut akan digunakan untuk belanja kegiatan operasional amil. Bagian Dana non syariah terdiri dari penerimaan dana bunga Bank sebesar Rp5.224.640. Nilai tersebut berasal dari bunga rekening di bank non syariah. Penyaluran dana non syariah tersebut hanya untuk membayar biaya administrasi bank sebesar Rp 570.500 dan pemotongan pajak oleh bank sebesar Rp 1.044.928.

Tabel 3. Analisis penyajian zakat dan infak/sedekah

\begin{tabular}{llc}
\hline \multicolumn{1}{c}{ Isi PSAK } & Implementasi pada BAZNAS Kab. Tegal & Keterangan \\
\hline Amil menyajikan dana zakat, dana & Amil telah menyajikannya secara terpisah dalam & \\
$\begin{array}{l}\text { infak/sedekah, dan dana amil secara } \\
\text { terpisah dalam laporan posisi } \\
\text { keuangan }\end{array}$ & laporan posisi keuangan & Sesuai \\
\hline
\end{tabular}




\section{Pengungkapan zakat dan infak/sedekah di BAZNAS Kabupaten Tegal}

BAZNAS Kabupaten Tegal belum mengungkapkan hal - hal terkait transaksi zakat dan infak/sedekah dalam laporan keuangan 2019 yang diatur dalam PSAK 109. Tidak dilakukannya pengungkapan tersebut karena amil kekurangan pegawai pada bagian keuangan dan belum adanya pegawai yang mempunyai latar belakang pendidikan akuntansi. Dalam proses pembuatan laporan keuangan, BAZNAS Kabupaten Tegal masih belajar dari BAZNAS Kabupaten Kendal yang telah lebih dahulu berdiri, dan belum dilaksanakan secara maksimal.

Tabel 4. Analisis pengungkapan zakat dan infak/sedekah

\begin{tabular}{llll}
\hline No. & \multicolumn{1}{c}{ Isi PSAK } & \multicolumn{1}{c}{$\begin{array}{c}\text { Implementasi pada BAZNAS Kab. } \\
\text { Tegal }\end{array}$} & Keterangan \\
\hline 1. & $\begin{array}{l}\text { Amil mengungkapkan hal-hal berikut } \\
\text { terkait dengan transaksi zakat, tetapi } \\
\text { tidak terbatas pada: huruf a s.d. f }\end{array}$ & $\begin{array}{l}\text { Amil belum mengungkapkannya pada } \\
\text { laporan keuangan 2019 }\end{array}$ & Tidak Sesuai \\
2. $\begin{array}{l}\text { Amil mengungkapkan hal-hal berikut } \\
\text { terkait dengan transaksi infak/sedekah, } \\
\text { tetapi tidak terbatas pada: huruf a s.d. h }\end{array}$ & $\begin{array}{l}\text { Amil belum mengungkapkannya pada } \\
\text { laporan keuangan 2019 }\end{array}$ & Tidak Sesuai \\
$\begin{array}{l}\text { Selain membuat pengungkapan di } \\
\text { paragraf 39 dan 40, amil } \\
\text { mengungkapkan hal-hal berikut: a) } \\
\text { keberadaan dana nonhalal; b) kinerja } \\
\text { amil atas penerimaan dan penyaluran } \\
\text { zakat dan infak/sedekah. }\end{array}$ & Amil belum mengungkapkannya pada & Tidak Sesuai \\
\hline
\end{tabular}

\section{PENUTUP}

\section{Simpulan}

Pengakuan zakat dan infak/sedekah oleh BAZNAS Kabupaten Tegal sebagian besar telah sesuai dengan ketentuan dalam PSAK 109, namun terdapat beberapa hal yang masih belum sesuai. Terdapat kesalahan periode pengakuan atas penerimaan zakat dan infak/sedekah yang diterima melalui rekening bank. Terhadap dana infak/sedekah yang disalurkan kepada amil lain seharusnya langsung diakui sebagai penyaluran infak/sedekah, namun BAZNAS Kabupaten Tegal masih mengakuinya sebagai piutang penyaluran, piutang penyaluran hanya diakui saat transaksi penyaluran dana zakat.

Pengukuran atas penerimaan dan penyaluran zakat dan infak/sedekah telah dilakukan sesuai ketentuan dalam PSAK 109. Untuk aset kas diukur sesuai jumlah yang diterima atau diserahkan, sedangkan untuk aset nonkas diukur sesuai nilai wajar yang diterima dan nilai tercatat yang diserahkan. Penentuan nilai wajar dilakukan oleh tim penilai BAZNAS Kabupaten Tegal.

Kegiatan penerimaan dan penyaluran zakat dan infak/sedekah yang dilakukan BAZNAS Kabupaten Tegal telah disajikan dalam laporan posisi keuangan, laporan perubahan dana, dan laporan aset kelolaan sesuai format yang disyaratkan. Namun demikian, pembuatan laporan keuangan belum memanfaatkan aplikasi penyusun laporan keuangan khusus amil. Penyusunan laporan keuangan masih menggunakan Aplikasi Excel yang rentan terjadi kesalahan dan kerusakan data. Aplikasi SIMBA yang berasal dari BAZNAS pusat hanya dimanfaatkan untuk pelaporan dana masuk dan pencatatan data muzaki. Amil belum menyusun laporan arus kas dan catatan atas laporan keuangan pada laporan keuangan 2019.

Pengungkapan atas hal-hal terkait transaksi zakat dan infak/sedekah tidak dilakukan oleh BAZNAS Kabupaten Tegal pada laporan keuangan 2019. Penentuan skala prioritas penyaluran, persentase pembagian, alasan, dan konsistensi kebijakan yang seharusnya diungkapkan baru dituangkan dalam rencana kerja dan anggaran tahunan (RKAT) yang disusun sebelum periode pelaporan berjalan. Pengungkapan terkait zakat dan infak/sedekah yang tidak diungkapkan dalam laporan keuangan juga terjadi karena kurangnya kemampuan dan jumlah pegawai di bagian keuangan.. 


\section{Saran}

Penelitian ini menyarankan untuk BAZNAS Kabupaten Tegal untuk melakukan perekrutan pegawai bagian keuangan yang memiliki latar belakang pendidikan akuntansi. Penggunaan aplikasi SIMBA sebagai pendukung dalam menyusun laporan keuangan juga perlu dimaksimalkan. Selain itu, pihak pengelola sebaiknya melakukan konsultansi dengan akuntan publik untuk meningkatkan kualitas laporan keuangan. Selain itu, BAZNAS Pusat sebagai induk dari BAZNAS yang berada di daerah sebaiknya meningkatkan pemberian pelatihan di bidang akuntansi zakat secara rutin dan berkesinambungan.

Penelitian ini hanya menggunakan satu objek penelitian sehingga tidak menggeneralisir untuk badan amil zakat lainnya. Oleh karena itu, dalam penelitian selanjutnya dapat menggunakan data dan informasi badan amil zakat lainnya untuk membandingkan penelitian tersebut dengan penelitian ini. Penelitian selanjutnya juga dapat membandingkan bagaimana perlakuan akuntansi zakat di Indonesia dengan negara lain yang memiliki organisasi pengelola zakat. Selain itu, penelitian selanjutnya juga dapat menggambarkan bagaimana tanggapan masyarakat terhadap amil sebelum menyajikan laporan keuangan sesuai standar dan setelah menyajikan laporan keuangan yang sesuai standar.

\section{DAFTAR PUSTAKA}

Amelia, E., \& Qibtiyah, M. (2015). Perlakuan akuntansi zakat berdasarkan psak 45 dan psak 109 pada bamuis BNI. Tauhidinomics: Journal of Islamic Banking and Economics, 1(2), 183-198. https://doi.org/10.15408/thd.v1i2.8435

Andriana, D. H., \& Sayidah, N. (2018). Penerapan akuntansi zakat dan infak / sedekah pada badan amil zakat nasional (baznas) Kabupaten Bojonegoro. Jurnal Analisa Akuntansi Dan Perpajakan, 2(2), 72-85. https://doi.org/10.25139/jaap.v2i2.1395

Angraeni, E. F., Pengemanan, S. S., \& Rondonuwu, S. S. (2016). Penerapan akuntansi zakat dan infak/sedekah berdasarkan PSAK 109 pada badan amil zakat Kota Bitung. Jurnal EMBA : Jurnal Riset Ekonomi, Manajemen, Bisnis Dan Akuntansi, 4(4), 1191-1199. https://doi.org/10.35794/emba.4.4.2016.15257

Arief, S. W. H. S., Manossoh, H., \& Alexander, S. W. (2017). Analisis penerapan PSAK No. 109 tentang akuntansi zakat, infaq/sedekah pada badan amil zakat nasional Kota Manado. Jurnal Riset Akuntansi Going Concern, 12(1), 98-107. https://doi.org/10.32400/gc.12.01.17142.2017

Aziz, A. (2014). Analisis penerapan PSAK 109 (studi analisis pada rumah zakat cabang Semarang). Institut Agama Islam Negeri Walisongo.

Baznas. (2019). BAZNAS salurkan hewan kurban di Kabupaten Tegal. https://baznas.go.id/pendistribusian/ekonomi/pemberdayaan-peternak/539-baznassalurkan-hewan-kurban-di-kabupaten-tegal

Djuanda, G. (2006). Pelaporan zakat pengurang pajak penghasilan. Raja Grafindo Persada.

Fathonah, F. (2013). Analisis penerapan akuntansi zakat pada organisasi pengelola zakat (studi kasus LAZISMU Kabupaten Klaten dan BAZDA Kabupaten Klaten) [Universitas Islam Negeri Sunan Kalijaga]. http://digilib.uin-suka.ac.id/id/eprint/11159/1/BAB I, V, DAFTAR PUSTAKA.pdf

Fitria, N. (2013). Analisis penyusunan laporan keuangan BAZNAS Kota Pekanbaru Menurut PSAK 109 [Universitas Islam Negeri Sultan Syarif Kasim]. http://repository.uinsuska.ac.id/5209/1/2013_2013287AKN.pdf

Habibatulloh, A. (2021). Analisis implementasi akuntansi zakat berdasarkan pernyataan standar akuntansi keuangan (PSAK) 109. JABE (Jurnal Akuntansi, Bisnis Dan Ekonomi), 10(2), 56-70. https://jurnal.stas.ac.id/index.php/jabe/article/view/40

Harahap, S. S. (2018). Teori akuntansi. Raja Grafindo. 
Hasibuan, H. T. (2020). Penerapan akuntansi zakat dalam meningkatkan transparansi dan akuntabilitas pengelolaan dana zakat, infak dan sedekah pada baznas Propinsi Bali. Jurnal Ilmu Manajemen Dan Akuntansi Terapan (JIMAT), 11(1), 133-148. https://doi.org/10.36694/jimat.v11i1.231

Ikatan Akuntan Indonesia. (2010). PSAK 109 Akuntansi Zakat dan Infak/Sedekah. In Standar Akuntansi Keuangan Syariah. Ikatan Akuntan Indonesia.

Ikatan Akuntan Indonesia. (2016). PSAK 101 tentang penyajian laporan euangan Syariah. In Standar Akuntansi Keuangan Syariah. Ikatan Akuntan Indonesia.

Isman, M. D. A. (2018). Penerapan akuntansi zakat, infaq, dan shodaqoh pada baitul ma'al hidayatullah di Balikpapan. Jurnal Ilmu Akuntansi Mulawarman, 3(4), 1-13. https://journal.feb.unmul.ac.id/index.php/JIAM/article/view/3188

Istikhomah, D., \& Asrori, A. (2013). Pengaruh literasi terhadap kepercayaan muzaki pada lembaga pengelola zakat dengan akuntabilitas dan transparansi sebagai variabel intervening. 2(1), 18-23. https://doi.org/10.15294/eeaj.v8i1.29763

Istutik, I. (2013). Analisis implementasi akuntansi zakat dan infak/sedekah pada lembaga amil zakat di Kota Malang. Jurnal Akuntansi Aktual, 2(1), 19-24. http://journal.um.ac.id/index.php/jaa/article/view/10445

Latifah, A. N., \& Mahrus, M. L. (2021). Penerapan PSAK 109 pada baznas kota magelang dan faktor- faktor yang memengaruhinya. Jurnalku, 1(4), 262-277. https://jurnalku.org/index.php/jurnalku/article/view/62

Loen, M. (2018). Analisis penerapan akuntansi zakat, infaq, shodaqoh pada badan amil zakat nasional (baznas) Provinsi Jawa Barat. Jurnal Akuntansi Dan Bisnis Krisnadwipayana, 5(3), 1-10. https://doi.org/10.35137/jabk.v5i3.230

Nikmatuniayah, N., \& Marliyati, M. (2015). Akuntabilitas laporan keuangan lembaga amil zakat di Kota Semarang. MIMBAR: Jurnal Sosial Dan Pembangunan, 31(2), 485. https://doi.org/10.29313/mimbar.v31i2.1562

Nurabiah, Pusparini, H., Fitriyah, N., \& Mariadi, Y. (2019). Implementasi PSAK 109 tentang akuntansi zakat, infaq, dan sedekah (studi pada badan amil zakat, infaq, sedekah di Kota Mataram). Aksioma: Jurnal Riset Akuntansi, 18(1), 22-56. https://doi.org/10.29303/aksioma.v18i1.52

Pertiwi, R. A., Kholmi, M., \& Kurniawati, E. T. (2017). Analisis penerapan akuntansi dana zakat dan infak/sedekah pada lembaga amil zakat infak, dan shodaqoh muhammadiyah (lazismu) Kabupaten Malang. Jurnal Reviu Akuntansi Dan Keuangan, 5(2), 751-758. https://doi.org/10.22219/jrak.v5i2.5151

Pratama, B. R. W., \& Roziq, A. (2017). Implementasi Akuntansi Zakat Infaq dan Shadaqah Berdasarkan PSAK 109 Implementation of Accounting Zakat, Infaq and Shadaqah Based on PSAK 109. E-Journal Ekonomi Bisnis Dan Akuntansi, 4(1), 35-39. https://jurnal.unej.ac.id/index.php/e-JEBAUJ/article/download/4565/3376

Ramadhita, R. (2012). Optimalisasi peran lembaga amil zakat dalam kehidupan sosial. Jurisdictie: Jurnal Hukum Dan Syariah, 3(1), 24-34. https://doi.org/10.18860/j.v0i0.2182

Ritonga, P. (2017). Analisis akuntansi zakat berdasarkan PSAK No. 109 pada badan amil zakat nasional Sumatera Utara. Kitabah: Jurnal Akuntansi Dan Keuangan Syariah, 1(1), 1-19. http://jurnal.uinsu.ac.id/index.php/JAKS/article/view/814

Saputra, M. F., \& Firmansyah, A. (2018). Analisis perpajakan terhadap bentuk usaha tetap berbasis layanan aplikasi. Jurnal Manajemen Keuangan Publik, 2(1), 1-22. https://doi.org/10.31092/jmkp.v2i1.295

Setda Kabupaten Tegal. (2020). Wakil bupati tegal salurkan bantuan BAZNAS untuk rehab rumah. http://setda.tegalkab.go.id/2020/01/14/wakil-bupati-tegal-salurkan-bantuanbaznas-untuk-rehab-rumah/ 
Journal of Law, Administration, and Social Science

Volume 1 No. 2, Desember 2021

Soemitra, A. (2009). Bank dan lembaga keuangan syariah. Kencana.

Sularno, M. (2010). Pengelolaan zakat oleh badan amil zakat daerah kabupaten/kota se Daerah Istimewa Yogyakarta (studi terhadap implementasi Undang-Undang No.38 Tahun 1999 tentang pengelolaan zakat). La_Riba: Jurnal Ekonomi Islam, 4(1), 35-45. https://doi.org/10.20885/lariba.vol4.iss1.art3 